\title{
Achievements and Challenges of CdS/CdTe Solar Cells
}

\author{
Zhou Fang, Xiao Chen Wang, Hong Cai Wu, and Ce Zhou Zhao \\ Department of Electrical and Electronic Engineering, Xi'an Jiaotong-Liverpool University, Suzhou 215123, China
}

Correspondence should be addressed to Ce Zhou Zhao, cezhou.zhao@xjtlu.edu.cn

Received 28 June 2011; Revised 8 August 2011; Accepted 8 August 2011

Academic Editor: Leonardo Palmisano

Copyright () 2011 Zhou Fang et al. This is an open access article distributed under the Creative Commons Attribution License, which permits unrestricted use, distribution, and reproduction in any medium, provided the original work is properly cited.

Thin film CdS/CdTe has long been regarded as one promising choice for the development of cost-effective and reliable solar cells. Efficiency as high as $16.5 \%$ has been achieved in CdS/CdTe heterojunction structure in laboratory in 2001, and current techniques for CdS/CdTe solar cells gradually step toward commercialization. This paper reviews some novel techniques mainly within two years to solve this problem from aspects of promotion of fabrication technology, structural modification, and choice of back contact materials.

\section{Introduction}

As the world is suffering from impending death of fossil fuels and serious pollution resulted from the fuels, solar energy is now regarded as one promising solution to the global energy crisis. Among various means for generating energy from the sun, solar cells are an effective approach to convert solar energy into practical electrical energy. In 2009, the global production of photovoltaic cells and modules in 2009 was $12.3 \mathrm{GW}$ [1], and it increased to over $20 \mathrm{GW}$ one year later [2]. Many kinds of solar cells based on Si [3], thin film [4, 5], or even organic materials $[6,7]$ are gradually developed these years. According to the US Department of Energy, solar energy should only be economically viable for large-scale production if the cost can be reduced to $\$ 0.33 / \mathrm{Wp}(\mathrm{Wp}=$ wart peak) [8].

Thin-film cadmium telluride (CdTe) is now regarded as one leading material for the development of cost-effective photovoltaics (PV), and it is also the first PV technology with the price for Wp below $\$ 1$ (\$0.85) [9]. CdTe has a band gap of $\sim 1.5 \mathrm{eV}$, which is close to the ideal value for photovoltaic conversion efficiency. Meanwhile, high optical absorption coefficient and high chemical stability also appear in CdTe. All of them make CdTe a very attractive material for thinfilm solar cells. The theoretical efficiency of CdTe thin-film solar cells is expected to be $28 \%-30 \%[10,11]$. Currently, First Solar has announced a new world record this year for CdTe PV solar cell efficiency of $17.3 \%$ with a test cell constructed using commercial-scale manufacturing equipment and materials, and its average efficiency of modules produced in the first quarter of 2011 was $11.7 \%$ [12].

One of best choices for CdTe cells are heterojunction structures with n-type cadmium sulfide (CdS) as a transparent window layer, and they are generally fabricated in a superstrate configuration (Figure 1). Despite the lattice mismatch of $10 \%$ between CdTe and CdS, the formed heterojunction has an excellent electrical behavior, leading to a high fill factor of 0.77 in produced solar cells [13]. Therefore, this structure is favored by a variety of worldleading corporates. For example, First Solar has launched one project to double its manufacturing capacity of $\mathrm{CdS} / \mathrm{CdTe}$ solar cells from $1.5 \mathrm{GW}$ at the beginning of 2011 to nearly $3 \mathrm{GW}$ by the end of 2012 [14]. Calyxo also expended their capacity up to $25 \mathrm{MWp}$ in 2008 and expects to finish their second production line with capacity of $110 \mathrm{MWp}$ in 2011 [15]. In CdS/CdTe heterojunction structure, efficiency up to $16.5 \%$ has been achieved in lab as early as 2001 [16], while the best commercial modules are approximately $10 \%-11 \%$ [17]. However, these are still much lower than the theoretical value. There are currently several challenges for further making CdS/CdTe thin-film solar cells more competitive: (1) short minority carrier lifetime due to the recombination of electron-hole pairs at the defect centers in CdTe layers and at the interface between CdS and CdTe, (2) insufficient transparency of transparent conductive oxide (TCO) and CdS window layers, (3) lack of good ohmic contact between CdTe layers and back contacts, and (4) possibility in doping p-type CdTe films in a stable way. Techniques coming up 


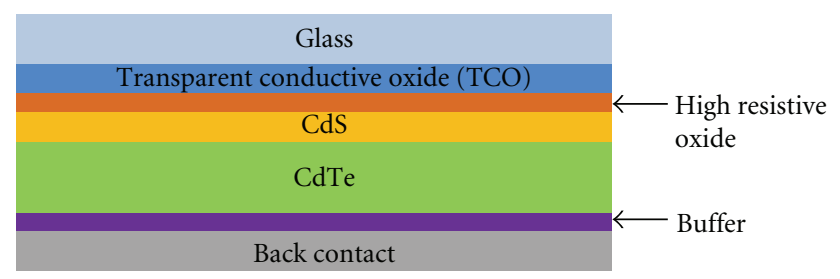

Figure 1: An example of the structure of standard CdS/CdTe thinfilm solar cells.

in recent years are mainly concentrated on the first three challenges above.

Instead of summarizing the history, this paper aims to review the progress of CdS/CdTe photovoltaics by evaluating some current techniques to deal with first three challenges above from three aspects: fabrication technology, structural design, and choice of back contact, respectively.

\section{Promotion in Fabrication Techniques}

Fabrication methods for CdS/CdTe layers could have a significant effect on cell efficiency and cost. Samples have been obtained successfully by several common techniques: radio frequency sputtering (R. F. Sputtering) [18], close-spaced sublimation (CSS) [19], and chemical bath deposition (CBD) [20] for CdS preparation, while electrodeposition (ED) [21], screen printing (SP) [22], and CSS [23-25] for CdTe thin-film formation. However, these methods are still not sufficient good due to their inherent drawbacks. For example, R. F. Sputtering for preparing CdS window layer can be rather fast but with poor quality that reduces the cell efficiency, while CBD could provide a dense and smooth CdS layer but the solution waste recycling and management cause extra cost. Therefore, the techniques should be carefully chosen with the consideration of high quality thin-film structure (high efficiency), proper pollution control, and commercial production prospect. Currently, the emerging problems related to fabrication mainly focus on (1) the short circuit of TCO and the CdTe layer caused by the partial grain covering and pinholes in CdS with extremely small thickness and (2) short minority carrier life time due to the defects inside the CdTe layer. Fortunately, several modifications to conventional methods and new techniques have been explored to improve the problems above these years [26-36].

2.1. Sputtering in $\mathrm{Ar}+\mathrm{CHF}_{3}$ Atmosphere. One excellent improvement to the fabrication of CdS layers is employing R. F. sputtering in the atmosphere of argon (Ar) containing 3\% of $\mathrm{CHF}_{3}$ [11, 26-29]. This gas is decomposed and ionized during the sputtering discharge, delivering electronegative fluorine (F) to the substrate. Although it has been proved that $\mathrm{F}$ does not reduce the resistance of CdS layers [11, 27, 29], compared with undoped CdS, F-doped CdS still exhibits a larger forbidden gap [26], a stronger photoconductivity, and, most importantly, gives higher-efficiency solar cells [27]. This phenomenon probably results from the presence of $F$.

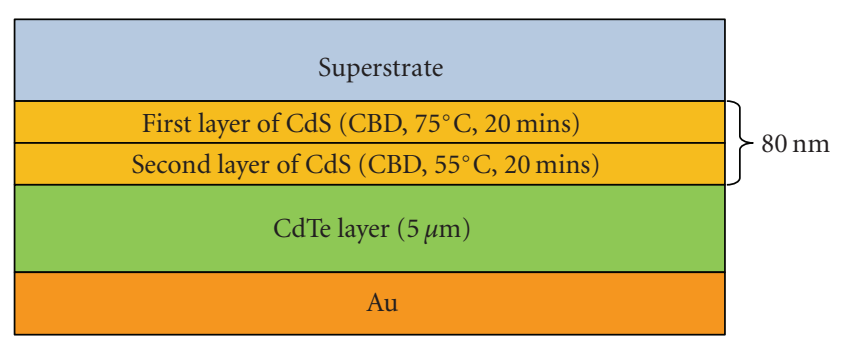

FIGURE 2: The structure of CdS/CdTe thin-film solar cell with bilayer CdS.

On one hand, it strongly reduces the growth rate of CdS and bombards the CdS films during the growth, which can eliminate the excess of $\mathrm{Cd}$ and $\mathrm{S}$, hence producing a dense film with excellent thickness and quality control $[28,29]$. On the other hand, it also promotes the formation of $\mathrm{CdF}_{2}$, which could passivate the grain boundaries and forming good CdS/CdTe junctions [11, 28, 29]. Efficiency as high as $15 \%-15.8 \%$ has been obtained by Bosio et al. [11] in this approach. Therefore, this technique can be treated as a good choice for the fabrication of CdS layers in industrial production of photovoltaic modules.

2.2. Bilayer CdS Thin-Film Preparation. The structure of the bilayer CdS thin-film solar cell is shown in Figure 2. In this technology, the first CdS layer is made by standard CBD process with reduced time (compared with standard structure shown in Figure 1), and then the second $\mathrm{CdS}$ layer is deposited by $\mathrm{CBD}$ at lower temperature $\left(55^{\circ} \mathrm{C}\right)$. Approximately $14.6 \mathrm{~nm}$ 's roughness was observed in atomic force microscopy (AFM) for standard CBD of CdS thin film, while it could be reduced to $7.2 \mathrm{~nm}$ in bilayer case (see in Figures 3(a) and 3(b), resp.). Then smaller grain size would be obtained since the bilayer structure could provide the compact and uniform CdS layers without pinholes and cracks among grain boundaries. The dense and smooth $\mathrm{CdS}$ thin films could generate isolation between TCO and CdTe layers, which could solve the shunt problem between these two layers. Moreover, thinner CdS film results in higher short-circuit current (Figure 4) and improved the efficiency by around $6.1 \%$ with less demand of material (only $80 \mathrm{~nm}$ thickness of CdS layer shown in Figure 2) compared with standard CBD process $[30,31]$.

2.3. Low-Temperature Deposition Method. An innovative low-cost trial through vacuum deposition (VD) is investigated to fabricate both $\mathrm{CdS}$ and CdTe on low-temperature $\left(-55^{\circ} \mathrm{C}\right)$ substrate [32]. The substrate holder was cooled by liquid nitrogen, while a secondary heater can adjust the temperature in a desired range. This process could provide higher optical transparency of CdS thin film and similar grain size (average $300 \mathrm{~nm}$ ) for both layers (see in Figures 5(a) and 5(b)) compared with conventional techniques. As the performance of the solar cell is closely related to the quality of the interface between CdS and CdTe, the similar grain size does favor to good intermixture of these 


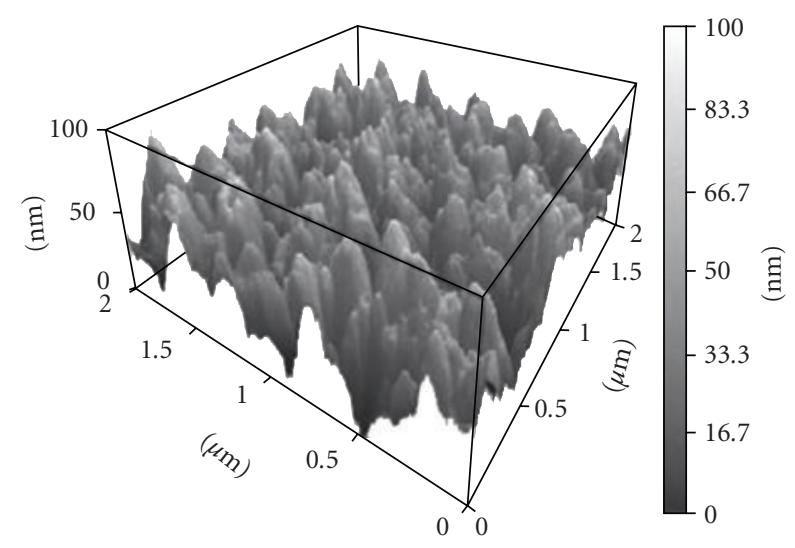

(a)

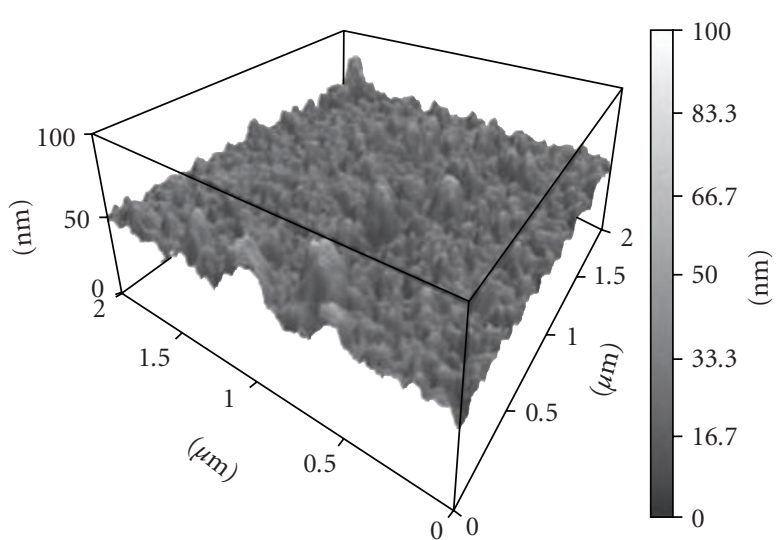

(b)

FIGURE 3: AFM of (a) standard CBD CdS with roughness of $12.2 \mathrm{~nm}$, (b) $\mathrm{CBD}$ CdS with $\mathrm{CdCl}_{2}$ annealing treatment at $300^{\circ} \mathrm{C}$ with roughness of $14.6 \mathrm{~nm}$, (c) bilayer CdS with total $80 \mathrm{~nm}$ thickness with roughness of $7.2 \mathrm{~nm}$. Figures are taken from [30].

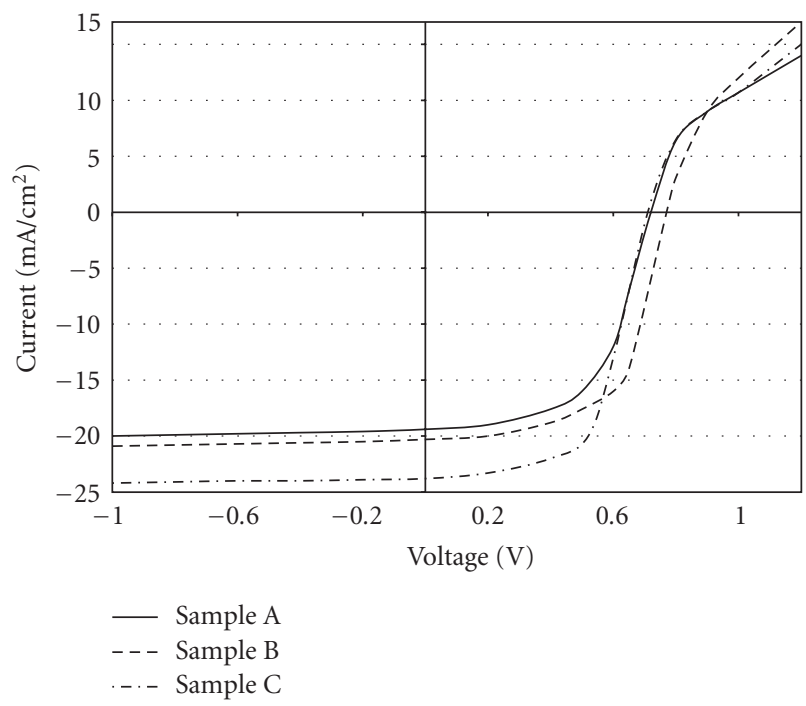

FIGURE 4: J-V characteristics of CdS/CdTe solar cells with different CdS films: Sample A: standard CBD CdS; Sample B: CBD CdS with $\mathrm{CdCl}_{2}$ annealing treatment at $300^{\circ} \mathrm{C}$; Sample C: bilayer CdS with total $80 \mathrm{~nm}$ thickness. Figures are taken from [30].

two materials and could dramatically decrease the defects inside interface. The resulted conversion efficiency $>14 \%$ is rather high since it is the first successful operation of CdS/ CdTe-based solar cell prepared by low-temperature deposition, and more work should be done to optimize the process before actually applying for commercial purpose [33].

2.4. All-Electrodeposited Method. In the all-electrical-deposition (AE) processing for CdS thin film, a graphite anode and a glass/fluorine-doped tin oxide (FTO) cathode are applied to pass an electric current through the electrolyte with $\mathrm{CdCl}_{2}$ and $\mathrm{Na}_{2} \mathrm{~S}_{2} \mathrm{O}_{3}$ dissolved in $(\mathrm{pH}=1.40)$ as shown in Figure 6. Both $\mathrm{Cd}$ - and S-containing cations are deposited on the cathode surface with electrically discharging and chemically reaction. The formation of $\mathrm{CdS}$ on the cathode can be represented by following mechanisms:

$$
\begin{gathered}
\mathrm{Cd}^{2+}+2 \mathrm{e}^{-} \longrightarrow \mathrm{Cd} \\
\mathrm{Na}_{2} \mathrm{~S}_{2} \mathrm{O}_{3}+\mathrm{H}_{2} \mathrm{O}+2 \mathrm{H}^{+} \longrightarrow 2 \mathrm{Na}^{+}+\mathrm{H}_{2} \mathrm{~S}_{2} \mathrm{O}_{3}+\mathrm{H}_{2} \mathrm{O} \\
\mathrm{H}_{2} \mathrm{~S}_{2} \mathrm{O}_{3} \longrightarrow \mathrm{H}_{2} \mathrm{SO}_{3}+\mathrm{S} \\
\mathrm{Cd}+\mathrm{S} \longrightarrow \mathrm{CdS}
\end{gathered}
$$

Daily waste of toxic Cd-contained solution during the production could be avoided since the bath for ED-CdS can be used for at least 18 months without discarding the electrolyte compared with CBD process. Furthermore, the CdS/CdTe thin-film solar cells achieve a similar or superior performance by applying ED-CdS instead of CBD-CdS, because the crystal structure is hexagonal for former and cubic for latter. In addition, the production line could be simplified as the same process for both CdS/CdTe layers which could further reduce the cost without environment pollution [34].

2.5. Dry $\mathrm{CdCl}_{2}$ Treatment for CdTe Recrystallization. Conventionally, CdS/CdTe samples are immersed into the solution containing $\mathrm{CdCl}_{2}$ and heated at $400-500^{\circ} \mathrm{C}$ in order to enlarge the grains inside the CdTe layers and eliminate defects to increase the minority carrier lifetime. However, it seems to be unsuitable for large area manufacture considering industrial production and the residue of the solute may not be thoroughly cleared up. To solve this problem, Lee's work [35] shows that the dry $\mathrm{CdCl}_{2}$ treatment by physical vapor deposition (PVD) on the sputtered CdTe layer. This method reveals effective process since no vacuum breaks are involved in production line, which agrees with commercial prospects. Furthermore, the average lower transmittance than wet treatment reflects its better light absorption property (Figure 7, the curve for dry $\mathrm{CdCl}_{2}$ treatment is obviously below the wet one) [35]. 


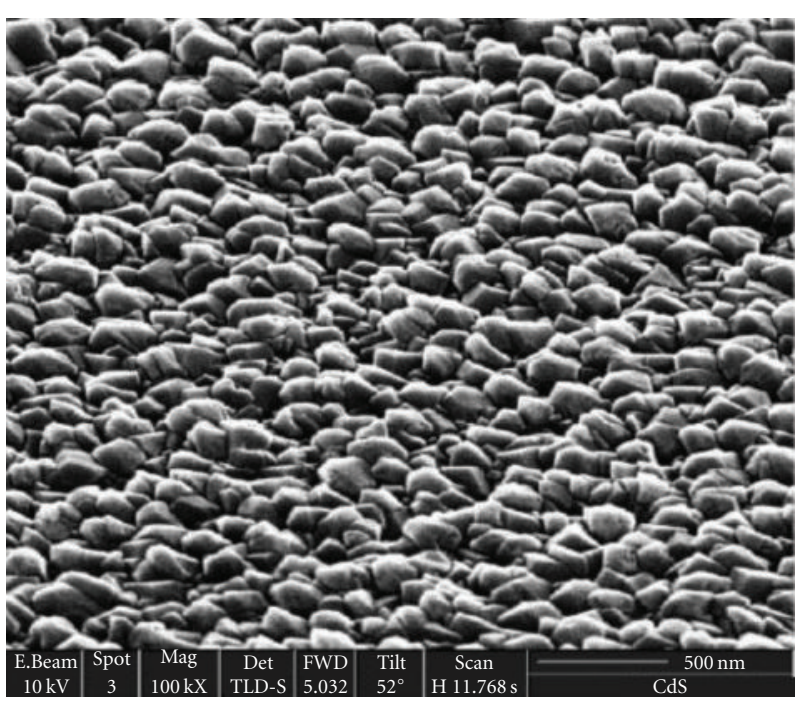

(a)

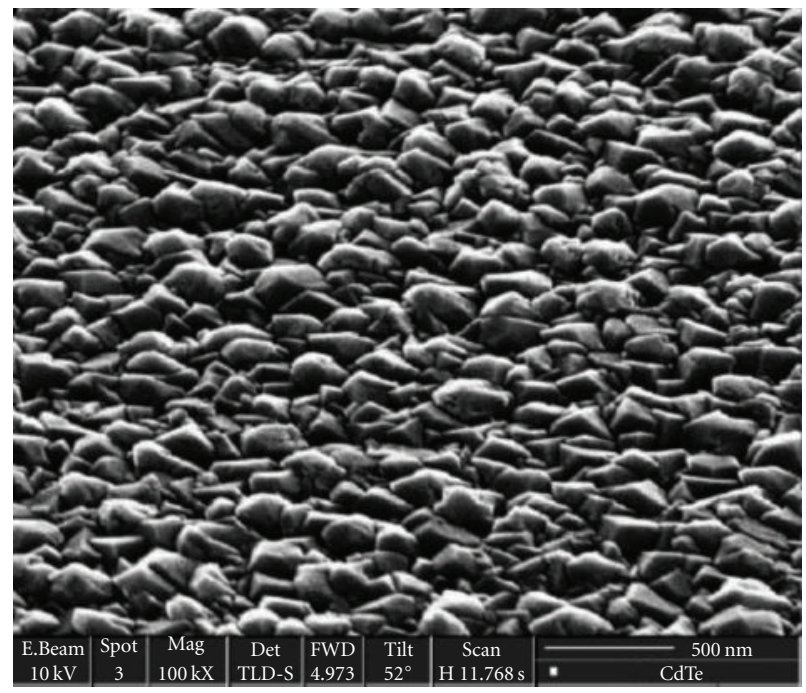

(b)

FIGURE 5: SEM photomicrographs of (a) CdS thin films prepared at $218 \mathrm{~K}$ substrate temperature, (b) CdTe thin films prepared at $218 \mathrm{~K}$ substrate temperature. Figures are taken from [33].

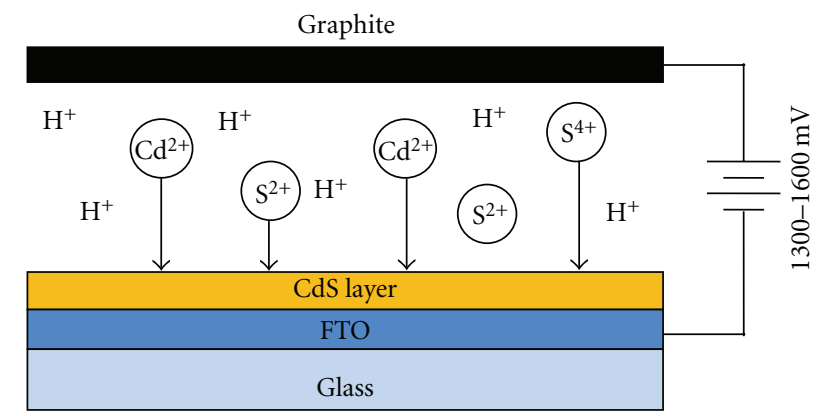

FIGURE 6: Electrodeposition process of CdS with graphite anode and glass/FTO cathode.

2.6. Nontoxic Chlorine Ambient Treatment. As the heat treatment with $\mathrm{CdCl}_{2}$ would bring both pollutions to environment and toxic threats to operators, nontoxic process is expected to be explored while retaining the efficiency of solar cells. Romeo et al. [29] provide a solution: to anneal the CdS/CdTe structure in mixture of 100-500 mbar of Ar and 20-50 mbar of nontoxic gas containing $\mathrm{Cl}_{2}$ such as difluorochloromethane $\left(\mathrm{HCF}_{2} \mathrm{Cl}\right)$ for $5-10$ minutes at $400^{\circ} \mathrm{C}$. $\mathrm{HCF}_{2} \mathrm{Cl}$ is stable, inert, and nontoxic at room temperature, and it would be decomposed as $\mathrm{Cl}_{2}$ and other products during annealing. Hence, the reactions below are supposed to happen:

$$
\begin{aligned}
& \text { CdTe }(\mathrm{s})+2 \mathrm{Cl}_{2}(\mathrm{~g}) \longrightarrow \mathrm{CdCl}_{2}(\mathrm{~g})+\mathrm{TeCl}_{2}(\mathrm{~g}) \\
& \mathrm{CdCl}_{2}(\mathrm{~g})+\mathrm{TeCl}_{2}(\mathrm{~g}) \longrightarrow 2 \mathrm{Cl}_{2}(\mathrm{~g})+\mathrm{CdTe}(\mathrm{s})
\end{aligned}
$$

The resultant CdTe solid in second chemical reaction (2b) would have larger grain size than the one in first reaction (2a) since annealing process in chlorine ambient assists the recrystallization of CdTe grains. The merits of this method are

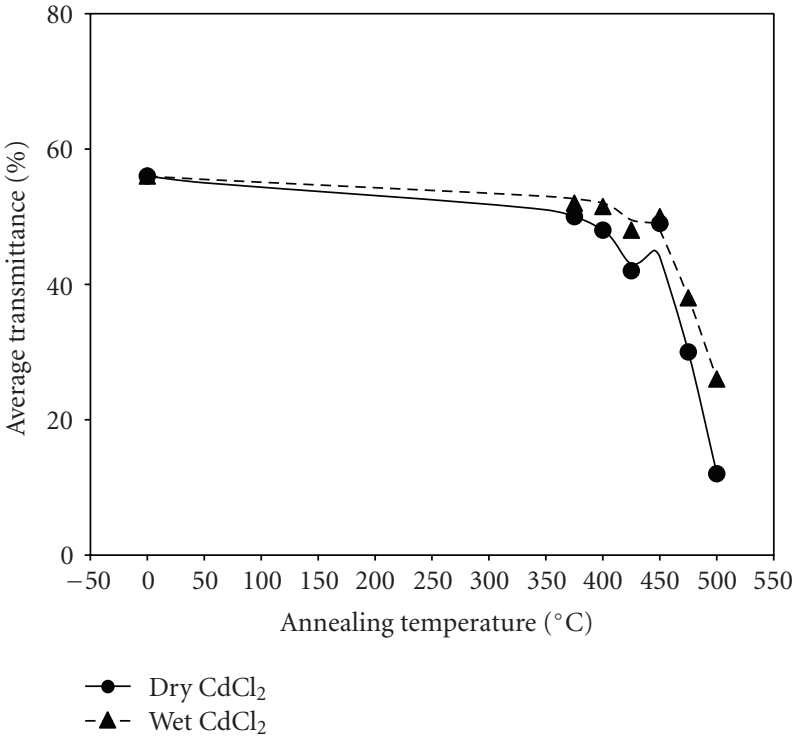

FIGURE 7: Average transmittance in the range of $800-100 \mathrm{~nm}$ for CdTe films annealed at different temperatures with dry and wet $\mathrm{CdCl}_{2}$ treatment. The films were deposited on ITO-coated glass substrate instead of CdS/ITO/glass substrate. Figure is taken from [35].

that it provides an effective way of producing high-quality CdTe layers with large grains and few defects (Figures 8(a) and $8(\mathrm{~b})$ ) to obtain less possibility of electron-hole recombination. The highest cell efficiency has reached $15.8 \%$. In addition, any gas of Freon family can be applied for carrying $\mathrm{Cl}_{2}$. Although the Freon gas with $\mathrm{Cl}$ is harmful to the ozone belt, the recovering machines are already commercially available. This process has been patented by Romeo et al. [36]. 


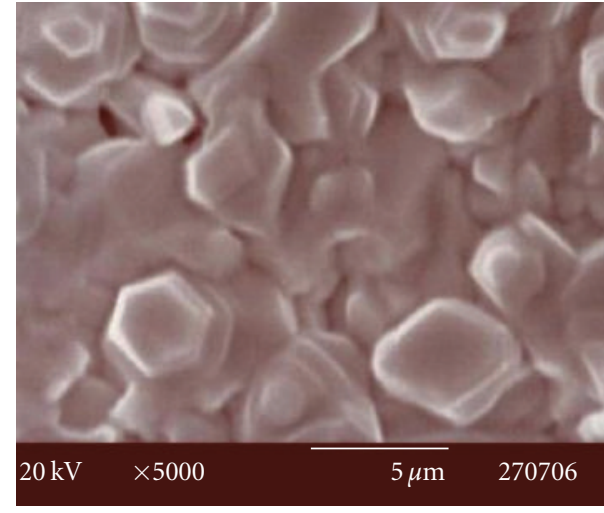

(a)

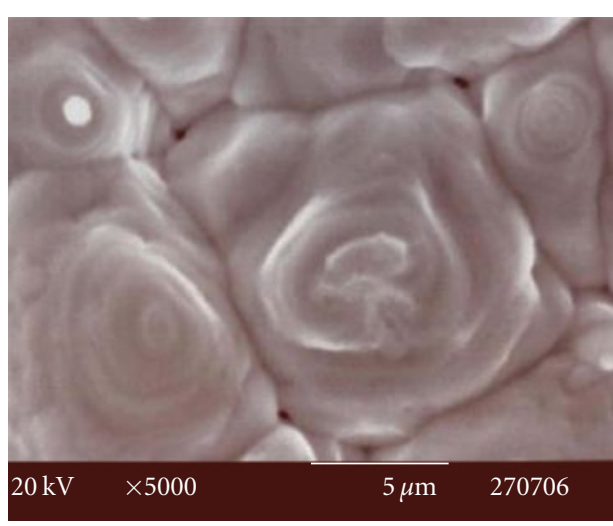

(b)

FIGURE 8: SEM photomicrographs of the surface of CdTe films: morphology of an untreated CdTe film deposited by the CSS method (a) before and (b) after thermal treatment in $\mathrm{Ar}+\mathrm{HCF}_{2} \mathrm{Cl}$ atmosphere at a temperature of $400^{\circ} \mathrm{C}$ for 5 min. Figure is taken from [29].

\section{Structural Modification}

The second approach to improve efficiency is to modify the configuration of CdS/CdTe solar cells. The favorable formation enthalpy and good chemical stability of CdS/CdTe heterojunction have allowed many routes to be explored in novel device architectures. In this part, two of them, namely nanostructure and tandem cells, are discussed.

3.1. Nanostructured Geometries. Nanostructured geometries are believed to be the most promising method to achieve high efficiency and low cost from structural aspect $[37,38]$. By employing nanopillar instead of planar CdS layer, on one hand, this provide excellent transparency of CdS layer, since the size of nanopillars is much smaller than the wavelength of visible light. On the other hand, light absorption is enhanced simultaneously due to quantum confinement effect. In addition, this approach also offers more flexibility, since the optical gap can be tuned by size variation of nanopillars. Currently, power conversion efficiency of $6.5 \%$ has been achieved by Liu et al. in this kind of structure [37], and it is expected to reach $>20 \%$ after further optimization [38].

The nanopillars can be directly built on or even embedded into CdTe with several methods (details in reference [39]), and one popular way is to employ anodized aluminum membrane (AAM) as the molds [37-39]. An excellent work of one three-dimensional (3D) nanopillar-array CdS/CdTe solar cell done by Fan et al. [40] is shown in Figure 9(a). A $\sim 2 \mu \mathrm{m}$ AAM with near-perfect ordering after anodization is built on $\mathrm{Al}$ substrate (Figure 9(b)), followed by a barrier thinning process to branch out the pore channels and reduce the AAM film to a few nanometers. After electrodepositing a thin layer of $\mathrm{Au}$ at the bottom of the channel, the nanopillar structure of CdS is then carried out in a quartz tube furnace with two resistive heating. In the third step, the AAM layer is partially etched by $\mathrm{NaOH}$ (Figure 9(c)) and a p-type CdTe film with $\sim 1 \mu \mathrm{m}$ is deposited by chemical vapor deposition (CVD). Finally, Cu/Au bilayer is grown on CdTe film by thermal evaporation to achieve low-barrier contact. This fabrication method can achieve high-density, single-crystal nanopillar array with good geometric control. This is an excellent breakthrough since it is difficult to keep highquality single-crystal structure when moving into nanometer level, and single crystal is usually required for high-efficiency solar cells to maintain high density of e-h pairs. Furthermore, it is also suggested that 3D nanopillar array can also improve the light absorption while enhancing the carrier collection efficiency [40]. The main limitation on its performance is the poor transparency of $\mathrm{Cu} / \mathrm{Au}$ layer (currently $50 \%$ only). Conversion efficiency of $\sim 6 \%$ has been reported in the initial design. To improve the efficiency, future research should focus on both the creation of high-quality singlecrystal nanopillar and understanding on pillar distribution and recombination rate of carriers in this structure.

3.2. Bifacial and Tandem Structure. Another popular structural solution of increasing efficiency is to build tandem cells. Bifacial configuration, the base of tandem connection, was developed in 1980s and then obtained renewed interests with intensive research after 2004 [41-44]. The basic idea is to replace conventional $\mathrm{Cu} / \mathrm{Au}$ with transparent indium tin oxide (ITO) as back contact layers. In this way, the solar cells can be illuminated from both sides, and, more importantly, the long-term stability can be improved due to the absence of bulk $\mathrm{Cu}$ layer [20]. The equivalent circuit of bifacial cells is now modeled as two opposite illuminated diodes representing main separating barrier and the barrier near the back contact, respectively [45]. Current efficiency achieved in CdS/CdTe bifacial structure has exceeded $10 \%$ and $3 \%$ on the front side and back side illumination, respectively [43]. It has also been shown that a very thin $\mathrm{Cu}$ layer can be added between CdTe and ITO to decrease the series resistance but still keeping the transparency $[43,45]$. If further reducing the thickness of CdTe layers in bifacial configuration, tandem cells can be built to increase the efficiency by absorbing a broader part of solar spectrum, though intensive researches are still required to make it into practice $[45,46]$. 


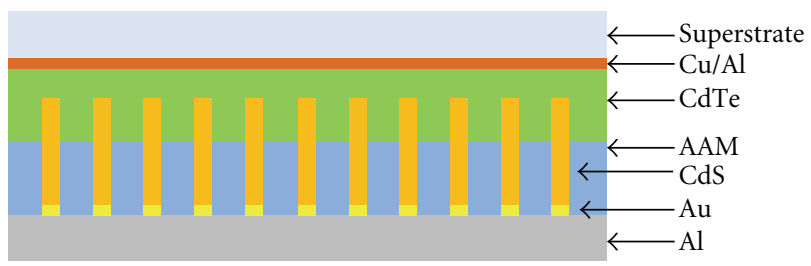

(a)

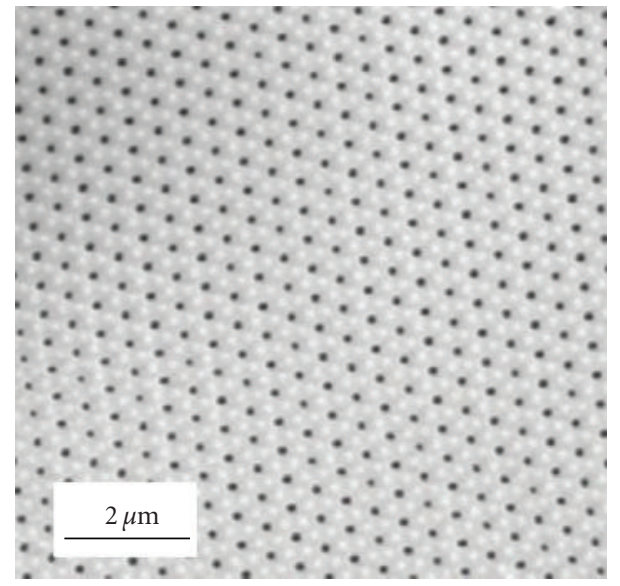

(b)

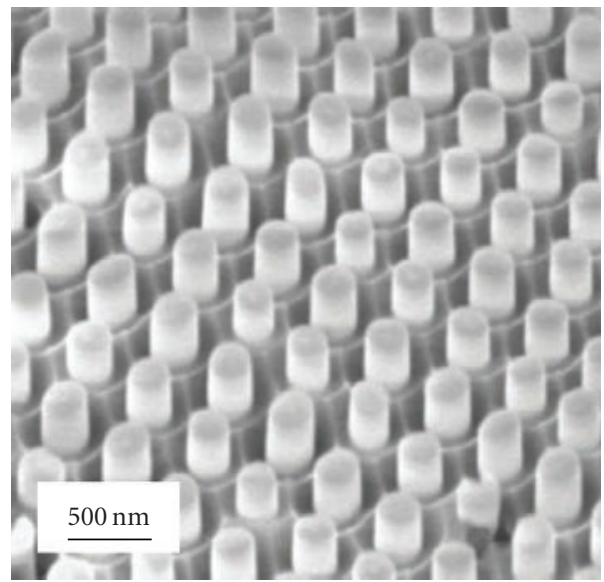

(c)

FIgure 9: (a) Cross-sectional schematic diagram of the solar nanopillar cell. (b) SEM images of an as-made AAM with perfectly ordered pores and (c) a CdS nanopillar array after partial etching of the AAM. Figures (b) and (c) are taken from [40].

\section{Choice of Back Contact}

Due to the high electron affinity of p-type CdTe, the Fermi level pinning would be formed between the absorption layer and the metal layer. A reverse-biased potential would be formed at the CdTe-metal interface to limit the holes' transport and would seriously reduce the cells' efficiency. Hence, an ohmic contact or tunneling contact is seriously required. Conventionally, an etching with nitric-phosphoric (NP) acid is applied to obtain Te-rich layers on the top of CdTe before copper deposition [11], so that a diffusion layer of $\mathrm{Cu}_{x} \mathrm{Te}$ alloy can be formed during the annealing after $\mathrm{Cu}$ deposition. Since $\mathrm{Cu}_{x} \mathrm{Te}$ exhibits p-type characteristics, a large amount of holes appear in $\mathrm{Cu}_{x} \mathrm{Te}$, and this offers a good ohmic contact with CdTe layers. Although it does help to provide tunneling contact and improve the cell performance, the roll over phenomenon can still not be avoided. Instead, a new etching technique employing nitric-acetic (NA) acid can be applied to avoid roll over phenomenon in J-V curve (Figure 10) and generate better ohmic contact with lower series resistance $\left(4.3 \Omega \mathrm{cm}^{2}\right)$ than that of NP acid etching method $\left(6.5 \Omega \mathrm{cm}^{2}\right)$ as well as higher fill factor [47].

Several novel techniques have been explored to suppress the large Schottky barrier and reduce the contact resistance at the CdTe-metal interface. One popular solution is to use $\mathrm{ZnTe}$ as a buffer layer between the CdTe layer and the $\mathrm{Cu}$ back contact. ZnTe has a similar lattice parameter with $\mathrm{CdTe}$, and the insertion of ZnTe layer produces an electrical field to reduce recombination loss of minority carriers at back contact surface $[48,49]$. Kim et al. [50] also shows that

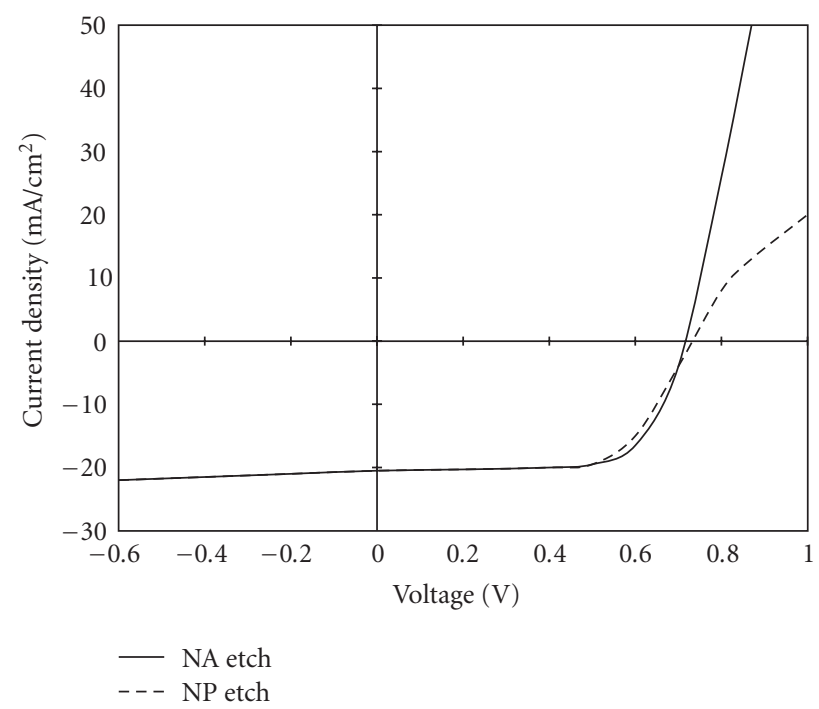

FIGURE 10: J-V characteristics of CdTe solar cells with different etching solutions applied. Figure is taken from [47].

double-layer structure with $\mathrm{Cu}$ doped $\mathrm{ZnTe}(\mathrm{ZnTe}: \mathrm{Cu})$ buffer and $\mathrm{Cu}_{x} \mathrm{Te}$ back contact can be very attractive for back contact fabrication, since $\mathrm{ZnTe}$ : $\mathrm{Cu}$ offers a good alignment of the valence band with $\mathrm{CdTe}$, while $\mathrm{Cu}_{x} \mathrm{Te}$, produced by bilayer deposition method, has an excellent crystallinity and contact with $\mathrm{CdTe}$ : Cu. Park et al. [51] have also reported that doping $\mathrm{ZnTe}$ : $\mathrm{Cu}$ with $\mathrm{Na}_{2} \mathrm{Te}$ can further improve 
the performance by decreasing the film resistance of $\mathrm{ZnTe}$ layer to $<1 \Omega \mathrm{cm}$. In addition, the stability can also be improved to a large extent if replacing the back contact metal of $\mathrm{Cu}$ into $\mathrm{Al}[52]$.

The use of $\mathrm{Cu}$ may reduce the long-term stability of solar cells, since $\mathrm{Cu}$ would gradually diffuse through grain boundaries reaching the interface of the junction and cause the shunt problem. Alternatively, some metals, such as $\mathrm{Ni}, \mathrm{Al}$, Mo, and W, can be employed to extend cell lifetime. Similarly, ohmic contact and metal diffusion barrier can be realized by a buffer layer inserted between CdTe and metal. $\mathrm{Sb}_{2} \mathrm{Te}_{3}$ is considered as a low-resistivity p-type material $\left(10^{-4} \Omega \mathrm{cm}\right)$ [29] that suitable for buffer layer with Mo or W metal contact to provide stable high-efficiency solar cell [11]. However, the performance highly depends on process condition and material purity, and the doping effect of Te into $\mathrm{Sb}_{2} \mathrm{Te}_{3}$ can be complicated [11]. $\mathrm{MoO}_{x}$, used as the buffer for $\mathrm{Ni}$ or $\mathrm{Al}$ contact, could remove the Te doping with relatively lower purity (99.95\%) and ultrathin CdTe cells, and efficiency of $>10 \%$ has been obtained [53]. An innovative way of $\mathrm{As}_{2} \mathrm{Te}_{3} / \mathrm{Cu} / \mathrm{Mo}$ bilayer buffer structure provides efficiency as high as $16 \%$, since the $\mathrm{Cu}_{x} \mathrm{Te}$ compound raises the conductivity in p-type material. As $\mathrm{As}_{2} \mathrm{Te}_{3}$ is directly deposited onto CdTe layer, no etching process is required. Moreover, an extremely thin $\mathrm{Cu}$ layer $(2-20 \mathrm{~nm})$ is inserted to get a low contact resistance without varying the stability. The controlled affinity of $x \leq$ 1.4 ensures cell stability without rectification [29].

\section{Conclusion}

This paper has summarized the latest research and techniques to solve the efficiency problem in $\mathrm{CdS} / \mathrm{CdTe}$ solar cells from aspects of fabrication, structure, and back contact materials. Although there is no impressive progress for efficiency improvement these years, those techniques above offer some novel ideas for further development. Based on the previous analysis, we still believe that CdS/CdTe solar cell will be a crucial candidate for global low-cost solar cells market in future.

\section{Acknowledgments}

This research was funded in part from the National Natural and Science Foundation of China under Grant no. 60976075, the Suzhou Science and Technology Bureau of China under Grant SYG201007, and SIP Service industry guiding funding.

\section{References}

[1] W. P. Hirshman, "Surprise, surprise (cell production 2009: survey)," Photon International, pp. 176-199, 2010.

[2] A. Sharma, "PV demand database-quarterly," IMS Research, 2011.

[3] B. Yan, G. Yue, X. Xu, J. Yang, and S. Guha, "High efficiency amorphous and nanocrystalline silicon solar cells," Physica Status Solidi A, vol. 207, no. 3, pp. 671-677, 2010.

[4] M. A. Green, "Thin-film solar cells: review of materials, technologies and commercial status," Journal of Materials Science in Electronics, vol. 18, no. 10, supplement 1, pp. S15-S19, 2007.

[5] V. Fthenakis, "Sustainability of photovoltaics: the case for thinfilm solar cells," Renewable and Sustainable Energy Reviews, vol. 13, no. 9, pp. 2746-2750, 2009.

[6] T. Kietzke, "Recent advances in organic solar cells," Advances in OptoElectronics, vol. 2007, Article ID 40285, 2007.

[7] L. Ren and S. Wang, "Progress of organic photovoltaic materials," Recent Patents on Materials Science, vol. 3, no. 1, pp. 2639, 2010.

[8] T. P. Kimbis, “Solar energy technology program,” US Department of Energy, 2011, http://wwwl.eere.energy.gov/solar/ pdfs/solar_program_mypp_2008-2012.pdf.

[9] V. Avrutin, N. Izyumskaya, and H. Morko, "Semiconductor solar cells: recent progress in terrestrial applications," Superlattices and Microstructures, vol. 49, no. 4, pp. 337-364, 2011.

[10] S. M. Sze, "Physics of semiconductor devices (2nd edition), Wiley, Amsterdam (1981)," Microelectronics Journal, vol. 13, no. 4, p. 44, 1982.

[11] A. Bosio, N. Romeo, S. Mazzamuto, and V. Canevari, "Polycrystalline CdTe thin films for photovoltaic applications," Progress in Crystal Growth and Characterization of Materials, vol. 52, no. 4, pp. 247-279, 2006.

[12] First Solar, "First solar sets world record for CdTe solar PV efficiency," 2011, http://investor.firstsolar.com/releasedetail.cfm ?ReleaseID=593994.

[13] X. Wu, "High-efficiency polycrystalline CdTe thin-film solar cells," Solar Energy, vol. 77, no. 6, pp. 803-814, 2004.

[14] S. Leone, " $\$ 4.5$ Billion in loans to support three first solar projects," Renewable Energy World, 2011, http://www.renewableenergyworld.com/rea/news/article/2011/07/4-5-in-loansto-support-three-first-solar-projects.

[15] C. Neumann, "CALYXO CdTe excellent yield per $\mathrm{W}_{\mathrm{p}}$ of the PV technologies," 2010, http://www.votum.cz/pdf/workshop/ Neumann\%20-\%20 Calyxo-\%20 Vynikajici\%20vyteznost $\% 20$ na\%20Wp.pdf.

[16] X. Wu, J. C. Keane, R. G. Dhere et al., "16.5\%-efficient CdS/ CdTe polycrystalline thin-film solar cells," in Proceedings of the 17th European Photovoltaic Solar Energy Conference and Exhibition (PVSEC'01), pp. 995-1000, 2001.

[17] M. Powalla and D. Bonnet, "Thin-film solar cells based on the polycrystalline compound semiconductors CIS and CdTe," Advances in OptoElectronics, vol. 2007, Article ID 97545, 2007.

[18] N. Romeo, A. Bosio, V. Canevari, M. Terheggen, and L. Vaillant Roca, "Comparison of different conducting oxides as substrates for CdS/CdTe thin film solar cells," Thin Solid Films, vol. 431-432, pp. 364-368, 2003.

[19] C. S. Ferekides, V. Ceekala, K. M. Dugan et al., "Reduction of recombination current in CdTe/CdS solar cells," Applied Physics Letters, vol. 67, no. 13, pp. 1896-1898, 1995.

[20] G. Khrypunov, A. Romeo, F. Kurdesau, D. L. Bätzner, H. Zogg, and A. N. Tiwari, "Recent developments in evaporated CdTe solar cells," Solar Energy Materials and Solar Cells, vol. 90, no. 6, pp. 664-677, 2006.

[21] G. C. Morris and S. K. Das, "Some fabrication procedures for electrodeposited CdTe solar cells," International Journal of Solar Energy, vol. 12, no. 1-4, pp. 95-108, 1992.

[22] S. Ikegami, "CdS/CdTe solar cells by the screen-printingsintering technique: fabrication, photovoltaic properties and applications," Solar Cells, vol. 23, no. 1-2, pp. 89-105, 1988.

[23] T. L. Chu and S. S. Chu, "High efficiency thin film CdS/CdTe solar cells," International Journal of Solar Energy, vol. 12, no. 1-4, pp. 121-132, 1992. 
[24] N. Romeo, A. Bosio, R. Tedeschi, A. Romeo, and V. Canevari, "Highly efficient and stable CdTe/CdS thin film solar cell," Solar Energy Materials and Solar Cells, vol. 58, no. 2, pp. 209218, 1999.

[25] J. Britt and C. Ferekides, "Thin-film CdS/CdTe solar cell with 15.8\% efficiency," Applied Physics Letters, vol. 62, no. 22, pp. 2851-2852, 1993.

[26] N. Romeo, A. Bosio, and V. Canevari, "The role of CdS preparation method in the performance of $\mathrm{CdTe} / \mathrm{CdS}$ thin film solar cells," in Proceedings of the 3rd World Conference on Photovoltaic Energy Conversion, vol. 1, pp. 469-470, Osaka, Japan, 2003.

[27] N. Romeo, A. Bosio, V. Canevari, and A. Podestà, "Recent progress on CdTe/CdS thin film solar cells," Solar Energy, vol. 77, no. 6, pp. 795-801, 2004.

[28] A. Podestà, N. Armani, N. Romeo, A. Bosio, G. Salviati, and M. Prato, "Influence of the fluorine doping on the optical properties of CdS thin films for photovoltaic applications," Thin Solid Films, vol. 511-512, pp. 448-452, 2006.

[29] N. Romeo, A. Bosio, and A. Romeo, "An innovative process suitable to produce high-efficiency CdTe/CdS thin-film modules," Solar Energy Materials and Solar Cells, vol. 94, no. 1, pp. $2-7,2010$.

[30] J. Han, C. Spanheimer, G. Haindl et al., "Optimized chemical bath deposited CdS layers for the improvement of CdTe solar cells," Solar Energy Materials and Solar Cells, vol. 95, no. 3, pp. 816-820, 2011.

[31] M. E. Calixto, M. Tufiño-Velázquez, G. Contreras-Puente et al., "Study of chemical bath deposited CdS bi-layers and their performance in CdS/CdTe solar cell applications," Thin Solid Films, vol. 516, no. 20, pp. 7004-7007, 2008.

[32] E. Bacaksiz, B. M. Basol, M. Altunbaş, V. Novruzov, E. Yanmaz, and S. Nezir, "Effects of substrate temperature and post-deposition anneal on properties of evaporated cadmium telluride films," Thin Solid Films, vol. 515, no. 5, pp. 30793084, 2007.

[33] V. D. Novruzov, N. M. Fathi, O. Gorur et al., "CdTe thin film solar cells prepared by a low-temperature deposition method," Physica Status Solidi A, vol. 207, no. 3, pp. 730-733, 2010.

[34] D. G. Diso, G. E. A. Muftah, V. Patel, and I. M. Dharmadasa, "Growth of CdS layers to develop all-electrodeposited CdS/CdTe thin-film solar cells," Journal of the Electrochemical Society, vol. 157, no. 6, pp. H647-H651, 2010.

[35] J. Lee, "Effects of heat treatment of vacuum evaporated $\mathrm{CdCl} 2$ layer on the properties of CdS/CdTe solar cells," Current Applied Physics, vol. 11, no. 1, pp. S103-S108, 2011.

[36] N. Romeo, A. Bosio, and A. Romeo, "Process for large scale production of $\mathrm{CdTe} / \mathrm{CdS}$ thin film solar cells," Patent No. US2004248340 (A1).

[37] P. Liu, V. P. Singh, C. A. Jarro, and S. Rajaputra, "Cadmium sulfide nanowires for the window semiconductor layer in thin film CdS-CdTe solar cells," Nanotechnology, vol. 22, no. 14, 2011.

[38] R. Kapadia, Z. Fan, and A. Javey, "Design constraints and guidelines for CdS/CdTe nanopillar based photovoltaics," Applied Physics Letters, vol. 96, no. 10, Article ID 103116, 2010.

[39] V. V. Kislyuk and O. P. Dimitriev, "Nanorods and nanotubes for solar cells," Journal of Nanoscience and Nanotechnology, vol. 8, no. 1, pp. 131-148, 2008.

[40] Z. Fan, H. Razavi, J. W. Do et al., "Three-dimensional nanopillar-array photovoltaics on low-cost and flexible substrates," Nature Materials, vol. 8, no. 8, pp. 648-653, 2009.

[41] T. Nakada, Y. Hirabayashi, T. Tokado, D. Ohmori, and T. Mise, "Novel device structure for $\mathrm{Cu}(\mathrm{In}, \mathrm{Ga}) \mathrm{Se}_{2}$ thin film solar cells using transparent conducting oxide back and front contacts," Solar Energy, vol. 77, no. 6, pp. 739-747, 2004.

[42] A. N. Tiwari, G. Khrypunov, F. Kurdzesau, D. L. Bätzner, A. Romeo, and H. Zogg, "CdTe solar cell in a novel configuration," Progress in Photovoltaics: Research and Applications, vol. 12, no. 1, pp. 33-38, 2004.

[43] A. Romeo, G. Khrypunov, S. Galassini, H. Zogg, and A. N. Tiwari, "Bifacial configurations for CdTe solar cells," Solar Energy Materials and Solar Cells, vol. 91, no. 15-16, pp. 13881391, 2007.

[44] S. Marsillac, V. Y. Parikh, and A. D. Compaan, "Ultra-thin bifacial CdTe solar cell," Solar Energy Materials and Solar Cells, vol. 91, no. 15-16, pp. 1398-1402, 2007.

[45] A. V. Meriuts, G. S. Khrypunov, T. N. Shelest, and N. V. Deyneko, "Features of the light current-voltage characteristics of bifacial solar cells based on thin CdTe layers," Semiconductors, vol. 44, no. 6, pp. 801-804, 2010.

[46] I. M. Dharmadasa, "Latest developments in CdTe, CuInGaSe and GaAs/AlGaAs thin film PV solar cells," Current Applied Physics, vol. 9, no. 2, pp. e2-e6, 2009.

[47] J. Han, C. Fan, C. Spanheimer et al., "Electrical properties of the CdTe back contact: a new chemically etching process based on nitric acid/acetic acid mixtures," Applied Surface Science, vol. 256, no. 20, pp. 5803-5806, 2010.

[48] N. Amin, K. Sopian, and M. Konagai, "Numerical modeling of CdS/CdTe and CdS/CdTe/ZnTe solar cells as a function of CdTe thickness," Solar Energy Materials and Solar Cells, vol. 91, no. 13, pp. 1202-1208, 2007.

[49] J. Sites and J. Pan, "Strategies to increase CdTe solar-cell voltage," Thin Solid Films, vol. 515, no. 15, pp. 6099-6102, 2007.

[50] S. H. Kim, J. H. Ahn, H. S. Kim, H. M. Lee, and D. H. Kim, "The formation of $\mathrm{ZnTe}: \mathrm{Cu}$ and CuxTe double layer back contacts for CdTe solar cells," Current Applied Physics, vol. 10, no. 3, pp. S484-S487, 2010.

[51] K. C. Park, E. S. Cha, and B. T. Ahn, "Sodium-doping of ZnTe film by close-spaced sublimation for back contact of CdTe solar cell," Current Applied Physics, vol. 11, no. 1, pp. S109S112, 2011.

[52] M. A. Matin, M. Mannir Aliyu, A. H. Quadery, and N. Amin, "Prospects of novel front and back contacts for high efficiency cadmium telluride thin film solar cells from numerical analysis," Solar Energy Materials and Solar Cells, vol. 94, no. 9, pp. 1496-1500, 2010.

[53] H. Lin, W. Xia, H. N. Wu, and C. W. Tang, "CdS/CdTe solar cells with $\mathrm{MoO}_{\mathrm{x}}$ as back contact buffers," Applied Physics Letters, vol. 97, no. 12, Article ID 123504, 2010. 


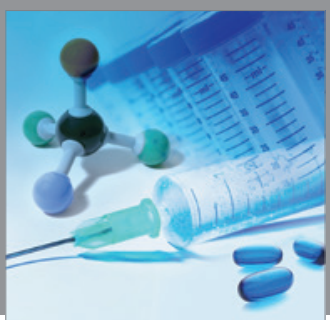

International Journal of

Medicinal Chemistry

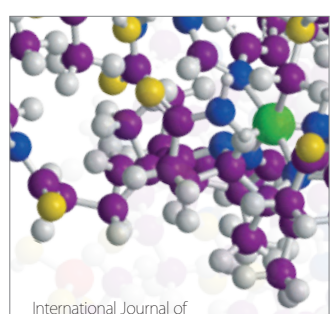

Carbohydrate Chemistry

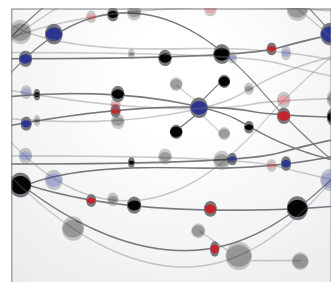

The Scientific World Journal
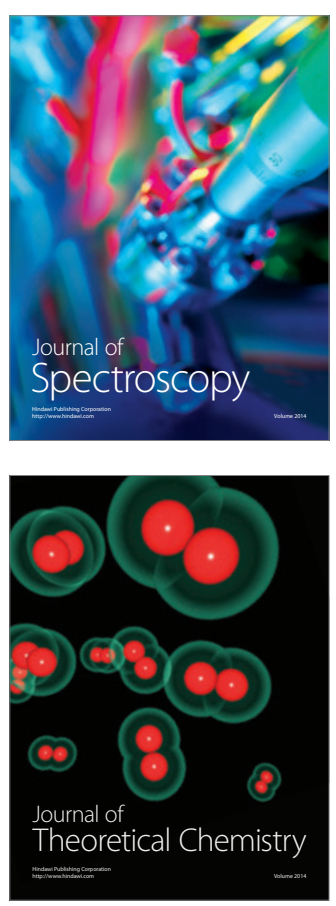
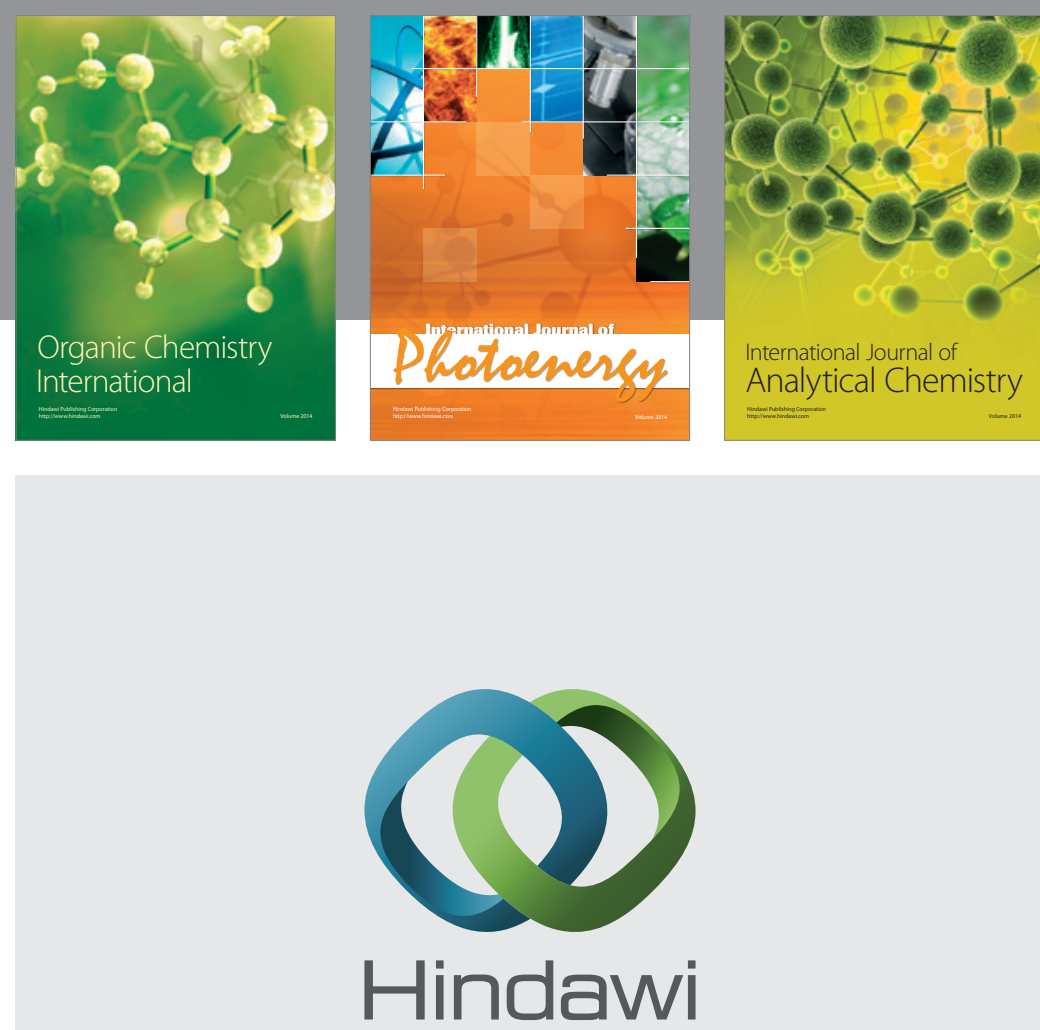

Submit your manuscripts at

http://www.hindawi.com
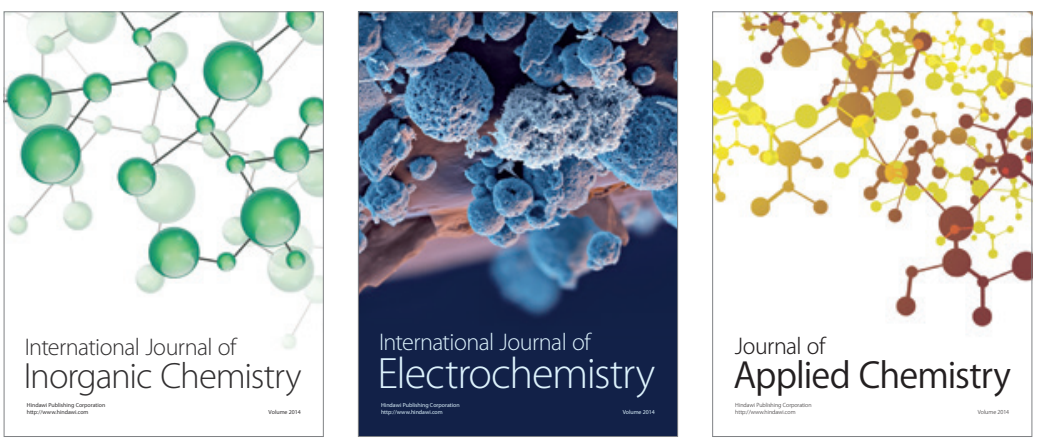

Journal of

Applied Chemistry
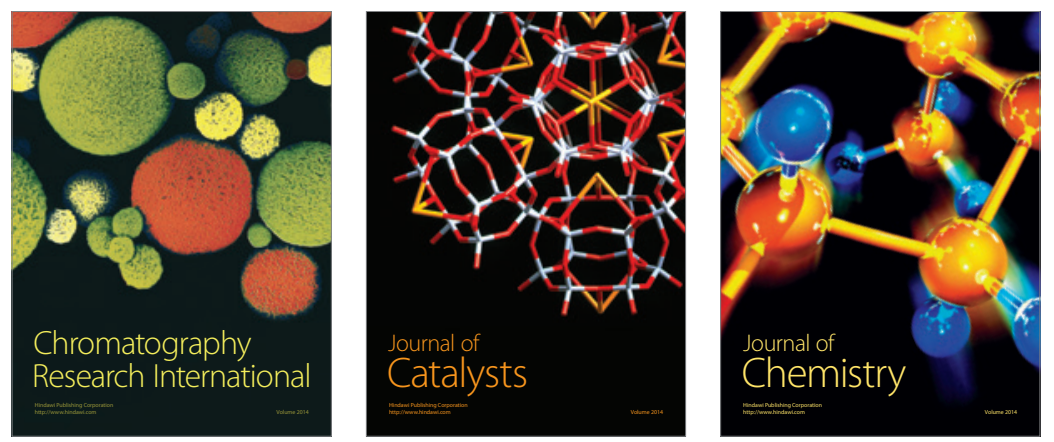
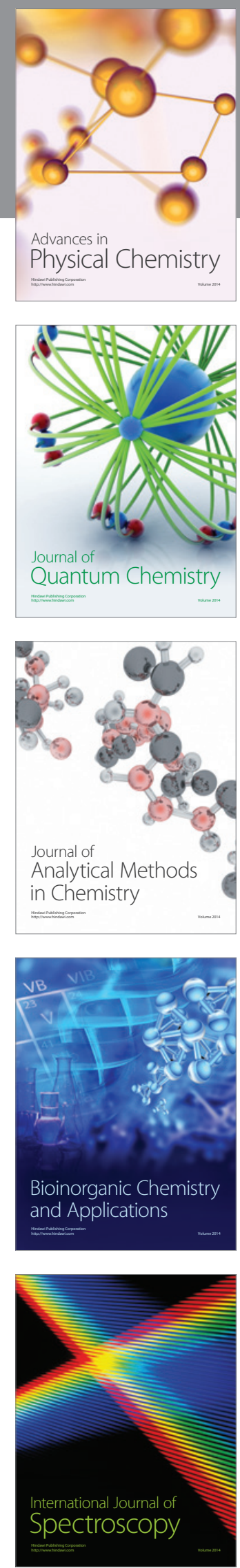